Muhammed Sabri Sirin

Erzincan Binali Yıldirım University

Department of Business

Administration

24100 Merkez/Erzincan, Turkey

sabri.sirin@erzincan.edu.tr
İlhami Yücel

Erzincan Binali Yıldırım University

Department of Business

Administration

24100 Merkez/Erzincan, Turkey

iyucel@erzincan.edu.tr
JEL: $M 12$

Original scientific article

https://doi.org/10.51680/ev.34.1.11

Received: September 11, 2020

Revision received: December 28, 2020 Accepted for publishing: January 12, 2021

This work is licensed under a Creative Commons AttributionNonCommercial-NoDerivatives 4.0 International License

\title{
THE RELATIONSHIP BETWEEN SUPERVISOR SUPPORT AND WORK-FAMILY CONFLICT AND THE MEDIATING ROLE OF WORK OVERLOAD PERCEPTION ON THIS RELATIONSHIP ${ }^{*}$
}

\section{Abstract}

Purpose: This study aims to investigate the mediating effect of work overload perception on the relationship between supervisor support and work-family conflict experienced by employees.

Methodology: The created models and hypotheses were tested on a sample comprising 401 research assistants working at a public university. The data obtained were analyzed using statistical programs.

Results: According to the results of the analyses, it was concluded that supervisor support had negative correlation with work-family conflict and work overload perception. In addition, a positive relationship between work overload perception and work-family conflict was observed.

Conclusion: Based on the mediation model that was used to test the main hypothesis, it was concluded that work overload perception has a partially mediating effect on the relationship between supervisor support and work-family conflict.

Keywords: Work overload, work-family conflict, supervisor support, mediating role, structural equation modeling

* This study is derived from the master's thesis titled "THE RELATIONSHIP BETWEEN WORK OVERLOAD AND WORKFAMILY CONFLICT AND THE ROLE OF SUPERVISOR SUPPORT IN THIS RELATIONSHIP", under the supervision of Dr. İlhami YÜCEL, at Erzincan Binali Yıldırım University, Institute of Social Sciences

\section{Introduction}

Working life has an essential place in the lives of employees and their families. Therefore, attitudes, behaviors and emotions towards work are important for both individuals and their families. The positive and negative situations experienced by employees 
in their working life affect them in a multidimensional way. Regardless of whether they work in the private sector or in public institutions, employees are faced with many problems in their working life. One of these problems is work overload perception. The concept of work overload perception is associated with the organization and the number of staff involved in the organization. Perceived work overload is a situation that has a detrimental effect on employees and may have negative consequences for both the staff and the organization (Fights, 2015). Work overload is a perception that the workload one has to deal with in the workplace or institution is above the required level (for example 40 hours of work per week). Work overload also means that work is too demanding and puts the individual under pressure (Greenberg et al., 2005). Conflict is a result of the incompatibility of goals, aspirations and aims of two or more people.

A role conflict is a situation emerging as a result of the discrepancy between the missions that individuals have and the lack of resources such as time, and energy to achieve these missions (Çarıkçı \& Çelikkol, 2009). Kahn (1964) described the role conflict as the pressures on the different roles of a person such that compliance with one makes it difficult to comply with the other. One of the factors affecting work-family conflict cited in the literature is work overload perception. An increase in work overload affects both the employee and his/her family and indirectly the organization (Ilies et al., 2007). In this context, supervisor support can affect the perception of work overload and thus reduce the work-family conflict. Based on the existing literature, the study seeks to investigate the mediating effect of work overload perception on the relationship between supervisor support and work-family conflict.

\section{Literature review and hypotheses}

Based on the spillover and social exchange theories, it can be concluded that supervisor support is related to work-family conflict. How a person perceives the support they receive from their supervisors may vary depending on employee perception of the facts (Broadbent, 1958). Therefore, if employees perceive supervisor support negatively, they may develop negative perceptions of work-family conflict as well. Supervisor support reduces work-family conflict (Adams et al., 1996; Byron, 2005; Michel et al., 2010). Supervisor support is defined and measured as the help given to employees striving to avoid work-family conflict, i.e., to achieve work-life balance. Support for employees seeking balance between work and family life includes work-related assistance, such as extending the deadline of the project, as well as emotional support, such as empathizing with an employee and showing interest in his/her well-being and family. Support in this context will have an effect similar to the effect of flexible working hours, that is, it will make it easier for employees to achieve balance between work and family roles. Once that balance has been achieved, the individual will be able to focus on tasks at hand, feeling emotionally relaxed and more energetic in the time allocated to the work. This is consistent with the theory of spillover (Staines, 1980), which argues that attitudes toward work can spread to the family sphere and affect perceptions of work-family conflict. Furthermore, the Social Exchange Theory, which studies human behavior in social interactions (Blau, 1964), offers another explanation for this relationship. The underlying assumption of the Social Exchange Theory is that people exchange resources to derive benefits for themselves (Emerson, 1976).

This theory is based on the idea of a subjective cost-benefit analysis in a relationship (Reiche et al., 2011). Within the scope of this study, the social exchange theory can be used to explain how employees balance the perceived exchanges between work and family. For example, people who are more satisfied with their salary experience fewer workfamily conflicts (Bhave et al., 2013). Accordingly, if employees' perceptions of supervisor support are positive, they perceive social exchange positively and work-family conflict decreases.

The lack of supervisor support in the workplace affects one's role in the family and at work (Kossek et al., 2011). Increased support will reduce conflict in the family and will improve employee focus and motivation. Prior research shows that there is a significant relationship between supervisor support and work-family conflict. In addition, a significant negative relationship was found between supervisor support and work-family conflict (O'Driscoll et al., 2003; Antani \& Ayman, 2004; Rousseau et al., 2006; 
Thompson \& Prottas, 2006; Breaugh \& Frye, 2008; Major et al., 2008; Mesmer-Magus et al., 2008; Ng \& Sorensen, 2008; Wang et al., 2010; Casper et al., 2011; Shirom et al., 2011). Based on the results of these studies, the following hypothesis is proposed:

H1: There is a significant negative relationship between supervisor support and work-family conflict.

Supervisor support is the extent to which employees feel that supervisors value, encourage and support them (Babin \& Boles, 1996). Muse and Pichler define a supervisor as the representative force that actually distributes resources by executing the organization's rules and policies. For this reason, the first premise of the general support that employees receive at work will be perceived as supervisor support (Muse \& Pichler, 2011). Supervisors, as representatives of the organization, are responsible for guiding employees and evaluating their performance (Eisenberger et al., 1986). In addition, employees often think that after evaluating subordinates, supervisors pass on the information on their performance to senior management, thus influencing senior management's views.

While supervisor support produces a number of positive effects on the employee, it also reduces the negative effects. Work overload perception is one of these negative effects. In order to reduce the perception of work overload, supervisor support to employees should be increased (Weigl et al., 2016). Supervisor support is negatively correlated with the perception of work overload. As supervisor support increases, the perception of work overload decreases. Previous research shows that there is a significant relationship between supervisor support and work overload perception. The relevant literature reports on a significant negative relationship between supervisor support and work overload perception (Kirmeyer \& Dougherty, 1988; Carlson \& Perrewe, 1999; Glaser et al., 1999; Yoon \& Thye, 2000; Fu \& Shaffer, 2001). Based on the results of these studies, the following hypothesis is put forward:

$\mathrm{H} 2$ : There is a significant negative relationship between supervisor support and work overload perception.

Work environment, the content and amount of work, and the number of negative experiences due to work constitute the structure of the work and cause work overload perception. Theoretically, when tasks are written down, it becomes clear what everyone has to do and how much workload there is. However, because each employee has different skills and capacities, the data on the paper may not always match the actual workload. For these reasons, the allocation of work according to the capabilities of employees will produce better results for both the organization and the employee (Keser, 2006).

Corporations and businesses seek to gain advantage over their competition. One of the secrets to successfully doing that is to make the most of the skills and capacities of their employees. Businesses that want to be successful in this context sometimes demand from their employees more than they can give. This leads to work overload. One of supervisor's tasks is to determine the workload of their subordinates. Role overload is defined as a situation in which employees are overwhelmed since they have too many responsibilities, which need to be performed well, and consequently they have to work longer hours (Greenhaus et al., 1989).

The concept of work-family conflict has been referred to in the literature using various terms such as work-family interaction problems, work-family mismatch and job-family tension. Role conflict was first defined by Kahn et al. (1964), who brought the work-family conflict in the focus of literature. A role is defined as a set of expectations that include variables such as the action, behavior and performance expected from a person in a social structure due to his status, environment and position. Work-family and family-work conflict is a result of the incompatibility of work and family roles and the difficulty to fulfill the requirements of the family role due to the requirements of the work role and vice versa (Greenhaus \& Beutell, 1985). It is defined as the demands of one role that affect and complicate the performance of the other role (Katz \& Kahn, 1978). Work-family conflict occurs as a result of a lack of communication between the roles of the person or the incompatibility of the two. It is a conflict arising from a person's failure to give the desired performance in one or both roles when he or she remains between these two roles (Clark, 2000). Greenhaus et al. (2003) argued that the following three elements are needed to achieve a work-family balance: 
Time balance - the necessity of allocating equal time to work and family roles; involvement balance - the balance of equal involvement in work and family roles; and satisfaction balance - equal satisfaction with work and family roles.

Increased social support from the organization, providing employees with the possibility of parttime work, flexible working hours, i.e., extending or reducing working hours on particular days are some of the strategies that can be employed to reduce work-family conflict (Albertsen et al., 2008; Joyce et al., 2010; Özmete \& Eker, 2012). One of the most impressive aspects of the human cognitive system is the ability to manage and execute multiple concurrent tasks. Concurrent multitasking (or simply multitasking) is a phenomenon that we encounter in our daily life, in our working life, and in our leisure time.

In some cases, multitasking may seem almost effortless (for example, walking and talking), in others, it may seem very difficult (for example, to read and listen at the same time) Multitasking performance can be highly dependent on the individual or the environment (for example, singing while playing an instrument or talking on the phone while driving). This area of possibilities creates tremendous difficulty in understanding the surprising capacity of the human system for multitasking on the one hand, and sometimes serious constraints on multitasking performance on the other (Salvucci \& Taatgen, 2008). In the context of multitasking theory, as the difficulty and the number of tasks increase, the perception of work overload occurs. Studies have shown that there is a significant relationship between work overload and work-family conflict.

Based on these studies, which have shown that there is a significant relationship between work overload and work-family conflict (Voydanoff, 1988; Carlson et al., 1995; Ahuja et al., 2007; Ilies et al., 2007; Lu et al., 2008; Ylldırım \& Aycan, 2008; Turgut, 2011; Goh et al., 2015), the following hypothesis is proposed:

H3: There is a significant positive relationship between work overload perception and work-family conflict.

\subsection{Work overload perception as a mediator of the relationship between supervisor support and work-family conflict}

Some ideas have been put forward to explain the impact of supervisor support and work overload perception on work-family conflict. According to multitasking, spillover and social exchange theories, supervisor support reduces the perception of work overload and the likelihood of work-family conflict (Staines, 1980; Salvucci \& Taatgen, 2008; Kossek et al., 2011).

Goh et al. (2015), on the basis of the preservation of resource theory, state that supervisor support helps employees cope with work overload and reduces work-family conflict. Goh found evidence of a relationship between work overload perception and work-family conflict, which had a significant impact on the work-private life balance. A supportive supervisor provides employees with the ability to manage job and family demands and can take supportive actions on certain issues related to the employee's career path or family issues (Kossek et al., 2011).

Experimental research shows that supervisor support is negatively associated with work-family conflict (Lapierre \& Allen, 2006; Kossek et al., 2011). In addition, research suggests that supervisor support provides employees with different resources and opportunities to reduce the negative impact of work overload perception. Employees who receive support from their supervisors in dealing with their workload and family issues are less likely to experience family conflict, even if the workload perception is high. In light of this, Shantz et al. (2016) examined the mediating effect of work overload on the relationship between HRM attributions and emotional exhaustion. Neither Shantz et al. (2016) nor other studies in the reviewed literature have looked at the mediating effect of work overload perception on the relationship between supervisor support and work-family conflict.

As a result of all these relations, it was concluded that work overload perception could play a mediating role in the relationship between supervisor support and work-family conflict. Thus, the following hypothesis was developed.

H4: Work overload perception has a mediating role in the relationship between supervisor support and work-family Conflict. 
Figure 1 Work overload perception as a mediator between supervisor support and work-family conflict
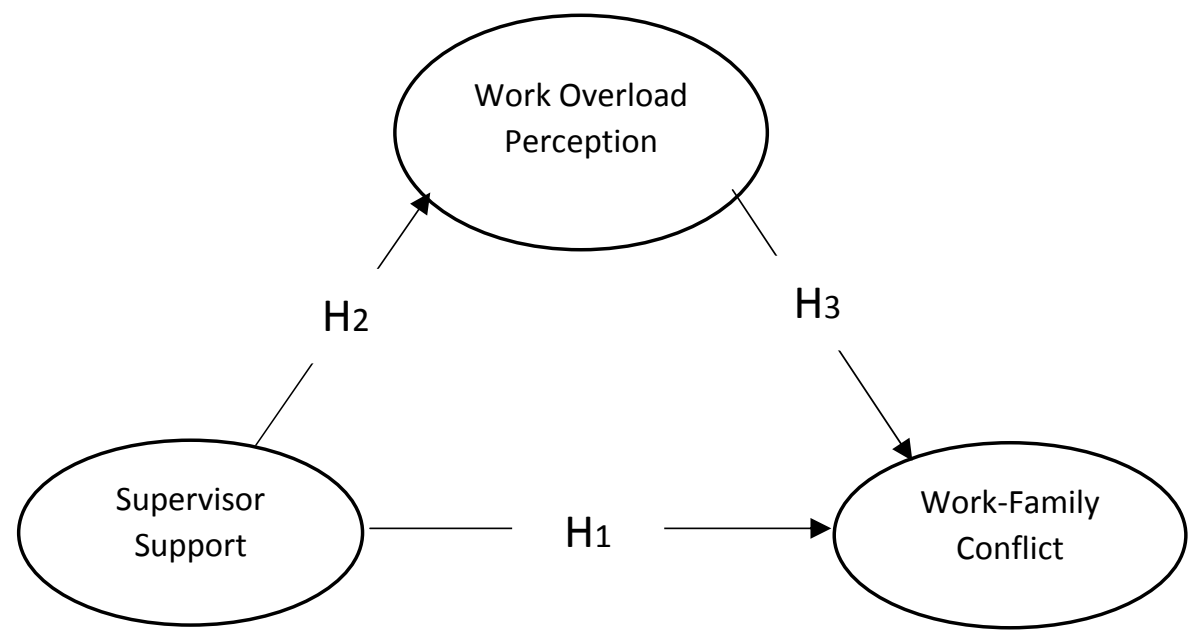

Note: Based on the mediation analysis, PROCESS MODEL 4 (Hayes, 2015)

Source: Authors

\section{Methodology}

\subsection{Sample and procedure}

Data were collected to investigate the mediating effect of work overload perception on the relationship between supervisor support and work-family conflict. A survey was conducted of research assistants working at a state university in Turkey. Survey questionnaires were sent to the respondents at the university. They were filled out and returned by 401 respondents. Before checking whether the created data set shows normal distribution or not, outlier analysis is applied to understand whether the data set has any outlier values. Extremely high or low values in the data set are called outlier values. These outliers may be caused by data entry errors or sampling errors. Extreme outlier values may cause the data set to deviate from normal distribution and affect statistical analysis (Ovla \& Taşdelen, 2012). As a result of the outlier analysis, no outliers were found. The subsequent normality test found that the data showed normal distribution. SPSS 22 was used to conduct the T-test, Anova, and exploratory factor analysis. AMOS 20 was used for the confirmatory factor analysis, bootstrapping and structural equation model. The Bootstrap method is one of the most frequently used methods in statistics. The main purpose of the Bootstrap method or algorithm is to create (generate) large data sets and to resample the data. In the Bootstrap method, the interpretation is made by redrawing some parameters with statistical inferences. This process is then repeated many times to be more reliable. With the Bootstrap method, variance estimates are successfully obtained and are frequently used for variance estimation (Preacher \& Hayes, 2004).

\subsection{Measures}

\section{Work Overload Perception}

A one-dimensional 5-item scale, developed by Imoisili (1985), was used as an independent variable to determine employees' work overload perception. Answers were measured on a 5-point Likert scale (1 = Strongly disagree, 2 = Disagree, $3=$ Undecided, 4 = Agree, 5 = Strongly agree). "I often do more work than I have to do" and "I often have to deal with difficult tasks" are some of the statements used in the scale. The Cronbach's alpha value, which shows the reliability coefficient of 0.91 , indicates that the scale is within acceptable limits.

\section{Work-Family Conflict}

A one-dimensional 5-item scale, developed by Netemeyer et al. (1996), was used as a dependent variable to determine whether employees have experienced work-family conflict. 
"Due to the requirements of my job, I have difficulty fulfilling my responsibilities towards my family", "The time I spend working makes it difficult for me to fulfill my responsibilities in the family" are some of the statements used in the scale. The Cronbach's alpha value, which shows the reliability coefficient of 0.96 , indicates that the scale is within acceptable limits.

\section{Supervisor Support}

A one-dimensional 6-item scale, which was developed by Anderson et al. (2002), was used as an intermediary variable to determine whether employees are provided support by the management. "When I have a problem, my department chair will support me", "My head of department is fair and does not favor certain employees over others" are some of the statements used in the scale. A Cronbach's alpha value of 0.96 indicates that the scale is within acceptable limits.

\subsection{Analyses and results}

\subsubsection{Supervisor support}

The reliability coefficient for the supervisor support scale was found to be 0.96 . The value of KMO (Kaiser-Meyer-Olkin Measure of Sampling Adequacy), which helps to determine whether the data are suitable for factor analysis, is found to be 0.91 , while Bartlett Test (Chi-square $=2789.522$, degrees of freedom $=15, \mathrm{p}=0.000$ ) seems to be significant. The six items in the scale were grouped under a single factor and the total variance was found to be 0.86 (Table 1).

Table 1 Factor analysis of the supervisor support scale

\begin{tabular}{|l|l|}
\hline Components & \% of variance \\
\hline Item 1 & .862 \\
\hline Item 2 & .882 \\
\hline Item 3 & .910 \\
\hline Item 4 & .932 \\
\hline Item 5 & .912 \\
\hline Item 6 & .927 \\
\hline
\end{tabular}

Source: Authors

According to the results of the analysis (Chi-square $=5.224$, degrees of freedom $=4, \mathrm{p}=0.000$ ) chisquare/degree of freedom was found to be 1.306 . Values less than 5 are acceptable for the goodnessof-fit of the model (Table 2). Confirmatory factor analysis of the scale is shown in Figure 2 The results of the analysis show that the standardized factor loadings of the model are all greater than 0.5 and all items have acceptable factor loadings.

Figure 2 Confirmatory factor analysis of the supervisor support scale

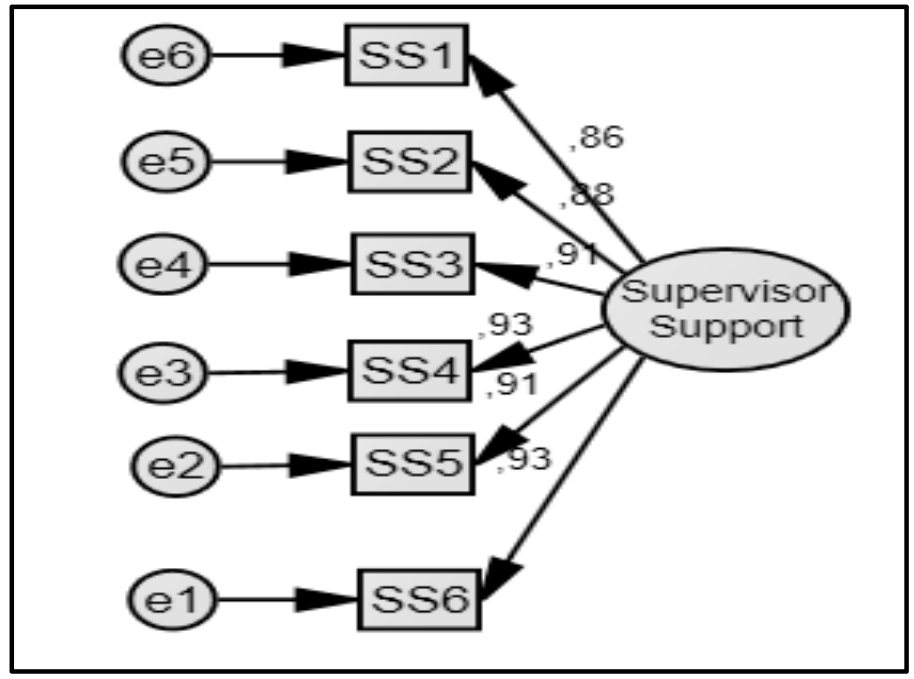

Source: Authors 
Table 2 Fit indices for the confirmatory factor analysis of supervisor support

\begin{tabular}{|l|l|l|l|l|l|l|l|l|l|}
\hline \multicolumn{1}{|c|}{ Variable } & \multicolumn{1}{|c|}{$\mathbf{X}^{\mathbf{2}}$} & \multicolumn{1}{c|}{$\mathbf{d f}$} & $\begin{array}{c}\text { CMIN/ } \\
\mathrm{DF} \leq \mathbf{5}\end{array}$ & $\begin{array}{c}\text { GFI } \\
\geq .85\end{array}$ & $\begin{array}{c}\text { AGFI } \\
\geq . \mathbf{8 0}\end{array}$ & $\begin{array}{c}\text { CFI } \\
\geq .90\end{array}$ & $\begin{array}{c}\text { NFI } \\
\geq .90\end{array}$ & $\begin{array}{c}\text { TLI } \\
\geq .90\end{array}$ & $\begin{array}{c}\text { RMSEA } \\
\leq .08\end{array}$ \\
\hline $\begin{array}{l}\text { Supervisor } \\
\text { Support (SS) }\end{array}$ & 5.224 & 4 & 1.306 & 0.984 & 0.944 & 0.975 & 0.994 & 0.996 & 0.045 \\
\hline
\end{tabular}

Source: Authors

Goodness-of-fit indices for the model are shown in Table 2. GFI, AGFI, CFI, NFI, TLI, RMSEA values are above the acceptable level.

\subsubsection{Work-family conflict}

The reliability coefficient for the work-family conflict scale was found to be 0.96 . The value of KMO (Kaiser-Meyer-Olkin Measure of Sampling Adequacy), which helps to determine whether the data are suitable for factor analysis, is found to be 0.91 , while Bartlett Test (Chi-square $=2412.928$, degrees of freedom $=10, p=0.000$ ) seems to be significant. The five items on the scale were grouped under a single factor and the total variance was found to be 0.86 (Table 3).
Table 3 Factor analysis of the work-family conflict scale

\begin{tabular}{|l|l|}
\hline Components & \% of variance \\
\hline Item 1 & .955 \\
\hline Item 2 & .954 \\
\hline Item 3 & .944 \\
\hline Item 4 & .912 \\
\hline Item 5 & .832 \\
\hline
\end{tabular}

\section{Source: Authors}

Confirmatory factor analysis of the work-family conflict scale is shown in Figure 3. The goodnessof-fit of the scale model is presented in Table 4. According to the results of the analysis (Chi-square $=5.863$, degrees of freedom $=4, \mathrm{p}=0.000)$ chisquare/degree of freedom was found to be 1.466 . Values less than 5 are acceptable for the goodnessof-fit of the model. The results of the analysis indicate that the standardized factor loadings of the model are all greater than 0.5 and all items have acceptable factor loadings.

Figure 3 Confirmatory factor analysis of the work-family conflict scale

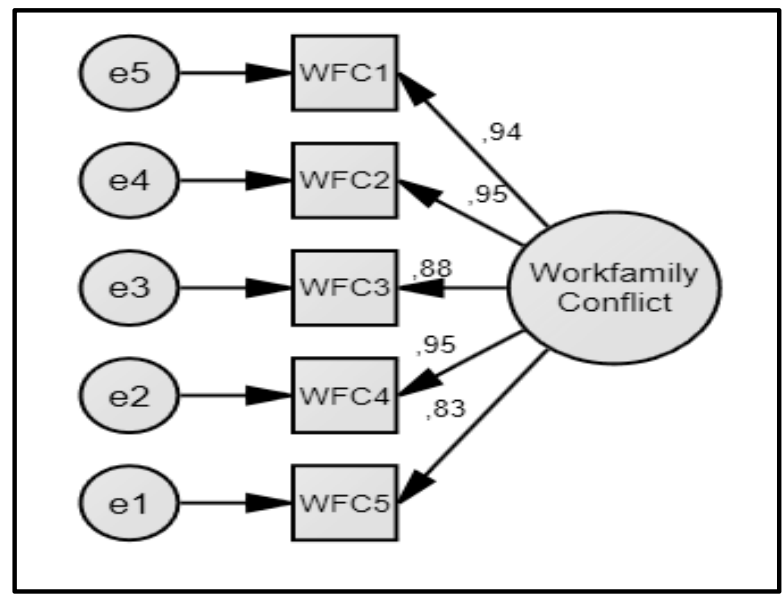

Source: Authors 
Table 4 Fit indices for the confirmatory factor analysis of work-family conflict

\begin{tabular}{|l|l|l|l|l|l|l|l|l|l|}
\hline \multicolumn{1}{|c|}{ Variables } & \multicolumn{1}{|c|}{$\mathrm{X}^{\mathbf{2}}$} & $\mathrm{Ddf}$ & $\begin{array}{c}\mathrm{CMIN} / \\
\mathrm{DF} \leq 5\end{array}$ & $\begin{array}{c}\text { GFI } \\
\geq .85\end{array}$ & $\begin{array}{c}\text { AGFI } \\
\geq .80\end{array}$ & $\begin{array}{c}\text { CFI } \\
\geq .90\end{array}$ & $\begin{array}{c}\text { NFI } \\
\geq .90\end{array}$ & $\begin{array}{c}\text { TLI } \\
\geq .90\end{array}$ & $\begin{array}{c}\text { RMSEA } \\
\leq .08\end{array}$ \\
\hline $\begin{array}{l}\text { Work-Family } \\
\text { Conflict (WFC) }\end{array}$ & 5.863 & 4 & 1.466 & 0.994 & 0.979 & 0.999 & 0.998 & 0.998 & 0.034 \\
\hline
\end{tabular}

Source: Authors

Goodness-of-fit indices are shown in Table 4. GFI, AGFI, CFI, NFI, TLI, and RMSEA values are above the acceptable level.

\subsubsection{Work overload perception}

The reliability coefficient of the work overload perception scale was found to be 0.91 . The value of KMO (Kaiser-Meyer-Olkin Measure of Sampling Adequacy), which helps to determine whether the data is suitable for factor analysis, is found to be 0.85, while Bartlett Test (Chi square $=1367.423$, degrees of freedom $=10, p=0.000$ ) seems to be significant. The five items on the scale were grouped under a single factor and the total variance was found to be 0.73 (Table 5).
Table 5 Factor analysis of the work overload perception scale

\begin{tabular}{|l|l|}
\hline Components & \% of variance \\
\hline Item 1 & .814 \\
\hline Item 2 & .739 \\
\hline Item 3 & .696 \\
\hline Item 4 & .792 \\
\hline Item 5 & .626 \\
\hline
\end{tabular}

\section{Source: Authors}

AMOS 20 statistical software was used for factor analysis. According to the results of the analysis (Chi-square $=5.920$, degrees of freedom $=4, \mathrm{p}=$ $0.000)$ chi-square/degree of freedom was found to be 1.480. Values less than 5 are acceptable for the goodness-of-fit of the model. Confirmatory factor analysis of the scale is shown in Figure 4. The results of the analysis show that the standardized factor loadings of the model are all greater than 0.5 and all items have acceptable factor loadings.

Figure 4 Confirmatory factor analysis of the work overload perception scale

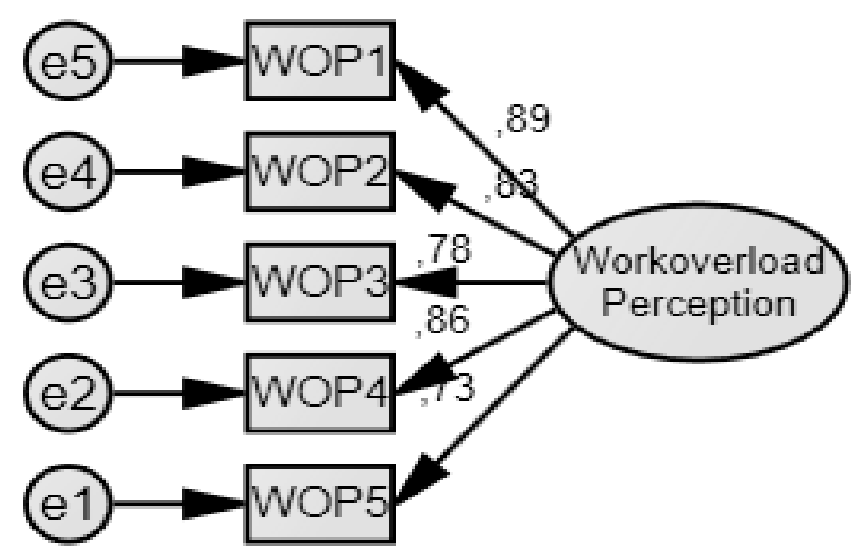

Source: Authors 
Table 6 Fit indices for the confirmatory factor analysis of work overload

\begin{tabular}{|l|l|l|l|l|l|l|l|l|l|}
\hline Variable & $\mathrm{X}^{2}$ & df & $\begin{array}{l}\text { CMIN/ } \\
\mathrm{DF} \leq 5\end{array}$ & $\begin{array}{l}\text { GFI } \\
\geq .85\end{array}$ & $\begin{array}{l}\text { AGFI } \\
\geq .80\end{array}$ & $\begin{array}{l}\text { CFI } \\
\geq .90\end{array}$ & $\begin{array}{l}\text { NFI } \\
\geq .90\end{array}$ & $\begin{array}{l}\text { TLI } \\
\geq .90\end{array}$ & $\begin{array}{l}\text { RMSEA } \\
\leq .08\end{array}$ \\
\hline $\begin{array}{l}\text { Work } \\
\text { Overload (WO) }\end{array}$ & 5.920 & 4 & 1.480 & 0.994 & 0.978 & 0.999 & 0.996 & 0.996 & 0.035 \\
\hline
\end{tabular}

Source: Authors

Goodness-of-fit indices for the model are shown in Table 6. GFI, AGFI, CFI, NFI, TLI, RMSEA values are above the acceptable level.

Figure 5 The mediating effect of work overload perception on the relationship between supervisor support and work-family conflict

Research Model

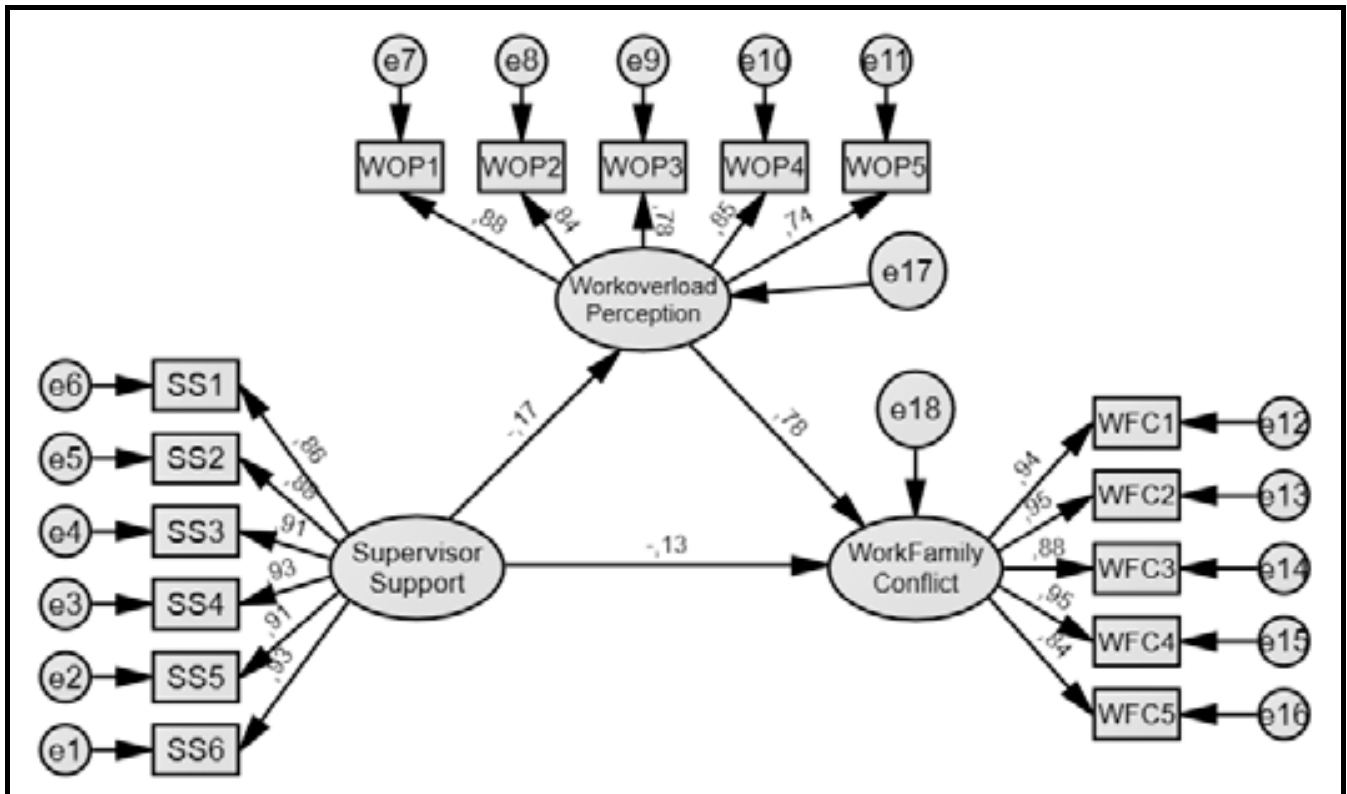

Source: Authors

Table 7 Fit indices for the research model

\begin{tabular}{|l|c|c|c|c|c|c|c|c|c|}
\hline Variable & \multicolumn{1}{|c|}{$\mathrm{X}^{\mathbf{2}}$} & df & $\begin{array}{c}\text { CMIN/ } \\
\mathrm{DF} \leq \mathbf{5}\end{array}$ & $\begin{array}{c}\text { GFI } \\
\mathbf{2 . 8 5}\end{array}$ & $\begin{array}{c}\text { AGFI } \\
\mathbf{2 . 8 0}\end{array}$ & $\begin{array}{c}\text { CFI } \\
\mathbf{2 . 9 0}\end{array}$ & $\begin{array}{c}\text { NFI } \\
\mathbf{2 . 9 0}\end{array}$ & $\begin{array}{c}\text { TLI } \\
\mathbf{2 . 9 0}\end{array}$ & $\begin{array}{c}\text { RMSEA } \\
\leq .08\end{array}$ \\
\hline Model & 219.73 & 100 & 2.197 & 0.934 & 0.911 & 0.983 & 0.969 & 0.980 & 0.05 \\
\hline
\end{tabular}

Source: Authors 
The goodness-of-fit indices for the confirmatory factor analysis of the scale presented in Table 7 show that the data were in accordance with the model. It was observed that supervisor support is negatively correlated with work-family conflict $(-0.192)$ and when adding the work overload perception to the model as a mediator variable, the relationship was reduced $(-0.130)$ (Table 8$)$. Therefore, work overload perception has a partially mediating effect on the relationship between supervisor support and work-family conflict. Thus, the hypotheses $\mathrm{H} 1, \mathrm{H} 2, \mathrm{H} 3$ and $\mathrm{H} 4$ are accepted at a 0.05 significance level.

Table 8 Significance level of the mediator variable

\begin{tabular}{|l|l|l|l|}
\hline Relation & Direct Effect & Mediated Direct Effect & Indirect Effect \\
\hline SP-WOP-WFC & $-0.192(0.000)$ & $-0.130(0.000)$ & -0.062 \\
\hline
\end{tabular}

Source: Authors

\section{Discussion}

Studies on supervisor support and work-family conflict suggest that supervisor support has an effect on life satisfaction through work-family conflict and increases it (Goh et al., 2015). Work overload perception has a mediating effect on the relationship between supervisor support and work-family conflict. The relationship between supervisor support and work-family conflict was high compared to the situations with low work overload perception.

This study examined the effect of supervisor support on work-family life with the mediating effect of work overload perception. The results suggest that supervisor support has a direct effect on workfamily conflict. Work overload perception increases work-family conflict without the supervisor support experienced by the employee. As supervisor support increases, work overload perception and work-family conflict decrease.

Previous studies have investigated the moderator effect of work overload perception. In contrast, this study examines the mediating effect of work overload perception on the relationship between supervisor support and work-family conflict. It was found that supervisor support to employees decreases the perception of work overload and therefore they experienced less work-family conflict. In addition, it was found that supervisor support affects workfamily conflict and that work overload perception has a partially mediating effect on this relationship.

Another difference between this study and previous research is that this study looks at academic staff and their perceptions. The most important reason why the sample for this study was drawn from academic staff is the fact that they have multiple roles (they teach courses, write scientific studies, work on their thesis and hold consultations with students at the same time), so their work overload perception is usually higher than in other professions. Particularly, late classes increase the possibility of work-family conflict.

\subsection{Limitations}

The data for this study were collected by a cross sectional study method. A cross-sectional study is conducted by collecting data at a single point in time from random samples representing subgroups of the population. One-time collection of data is one of the limitations of the study.

All scales used to collect data were prepared using a 5-point Likert scale. Using the same scale type for variables may lead to common method bias (Podsakoff et al., 2003). Common method bias is the probability that the relationships determined between the variables as a result of the research have been influenced by the measurement method. In other words, measuring all variables using Likert scale may have an impact on the evaluations of the respondents. Using Likert scale to measure all variables in this study may lead to common method bias. This is another limitation of the study.

\section{Conclusion and directions for future research}

This study was conducted to investigate the mediating effect of work overload perception on the relationship between supervisor support and work- 
family conflict. The study showed that supervisor support has a significant negative relationship with work-family conflict and that work overload perception has a partially mediating effect on this relationship.

Furthermore, the study found that supervisor support decreases work-family conflict experienced by the employee. Thus, the study contributes to the existing evidence on direct relationship between supervisor support and work-family conflict. Its findings are consistent with the findings of previous studies. They can be useful for organizations that seek to help their employees to reduce workfamily conflict. Another finding of the study is that work overload perception has a significant negative relationship with supervisor support and a significant positive relationship with work-family conflict. The main result of the study is that work overload perception has a partially mediating effect on the relationship between supervisor support and workfamily conflict. Work overload perception causes the link between supervisor support and workfamily conflict to weaken. In other words, increased perception of work overload increases work-family conflict even if supervisor support is strong. Since supervisor support is closely related to work-family conflict, organizations can develop strategies to reduce the conflict between individuals' work role and family role.

The research model was tested on research assistants at a state university in Turkey. To generalize the findings, the model should be applied in other sectors. Therefore, it is recommended to carry out studies in different fields.

There are some attitudes and behaviors of supervisors that can reduce the perceived work overload and the work-family conflict.

Supervisors should:

- develop policies to attain the most appropriate level of staff, which will reduce the workload perception of staff

- create an environment that promotes a healthy and sincere communication with their employees and support them in every sense

- distribute workload among their employees in a fair manner, and treat their staff fairly

- develop and promote an institutional culture to minimize the occurrence of work-family conflict among employees. 


\section{REFERENCES}

1. Adams, G. A., King, L. A. \& King, D. W. (1996). Relationships of job and family involvement, family social support and work-family conflict with job and life satisfaction. Journal of Applied Psychology, 81, 411-420. https://doi.org/10.1037/0021-9010.81.4.411

2. Ahuja, M., Chudoba, K., Kacmar, C., Mcknight, D. \& George, J. (2007). It road warriors: balancing work-family conflict, job autonomy, and work overload to mitigate turnover intentions. MIS Quarterly, 31(1), 1-17. https://doi.org/10.2307/25148778

3. Albertsen, K., Rafnsdóttir, G. L., Grimsmo, A., Tomasson, K. \& Kauppinen, K. (2008). Workhours and worklife balance. Scandinavian Journal of Work, Environment \& Health 34(5), 14.

4. Antani, A. \& Ayman, R. (2004). The relationship of ethnicity with social support and work-family conflict. Paper presented at the annual meeting of the Society for Industrial and Organizational Psychology, Chicago. https://doi.org/10.1037/e518632013-399

5. Babin B. J. \& Boles, J. S. (1996). The effects of perceived co-worker involvement and supervisor support on service provider role stress, performance and job satisfaction. Journal of Retailing, 72(1).

https://doi.org/10.1016/S0022-4359(96)90005-6

6. Bhave, D. P., Kramer, A. \& Glomb, T. M. (2013). Pay satisfaction and work-family conflict across time. Journal of Organizational Behaviour, 34, 698-713. https://doi.org/10.1002/job.1832

7. Blau, P. M. (1964). Exchange and Power in Social Life. Wiley.

8. Breaugh, J. A. \& Frye, N. K. (2008). Work-family conflict: the importance of family-friendly employment practices and family-supportive supervisors. Journal of Business and Psychology, 22(4), 345-353. https://doi.org/10.1007/s10869-008-9081-1

9. Broadbent, D. E. (1958). Perception and Communication. Oxford University Press. https://doi.org/10.1037/10037-000

10. Byron, K. (2005). A meta-analytic review of work-family conflict and its antecedents. Journal of Vocational Behavior, 67, 169-198. https://doi.org/10.1016/j.jvb.2004.08.009

11. Carlson, D. S. \& Perrewe, P. L. (1999). The Role of Social Support in the Stressor-Strain Relationship: An Examination of Work-Family Conflict. Journal of Management, 25(4), 513-540.

https://doi.org/10.1177/014920639902500403

12. Carlson, D. S., Michele Kacmar, K. \& Stepina, L. P. (1995). An Examination of Two Aspects of WorkFamily Conflict: Time and Identity. Women in Management Review, 10(2), 17-25.

https://doi.org/10.1108/09649429510084603

13. Casper, W. J., Harris, C., Taylor-Bianco, A. \& Wayne, J. H. (2011). Work-Family Conflict, Perceived Supervisor Support and Organizational Commitment Among Brazilian Professionals. Journal of Vocational Behavior, 79(3), 640-652. https://doi.org/10.1016/j.jvb.2011.04.011

14. Carıkçı, İ. H. \& Çelikkol, Ö. (2009). İş-Aile Çatışmasının Örgütsel Bağlılık ve İşten Ayrılma Niyetine Etkisi. Süleyman Demirel Üniversitesi Sosyal Bilimler Enstitüsü Dergisi, (9), 153-170.

15. Clark, S. C. (2000). Work/Family Border Theory: A New Theory of Work/Family Balance. Human Relations, 53(6), 747-770. https://doi.org/10.1177/0018726700536001

16. Eisenberger, R., Huntington, R., Hutchison, S. \& Sowa, D. (1986). Perceived Organizational Support. Journal of Applied Psychology, 71(3), 500. https://doi.org/10.1037/0021-9010.71.3.500

17. Emerson, R. M. (1976). Social Exchange Theory. Annual Review of Sociology, 2, 335-362. https://doi.org/10.1146/annurev.so.02.080176.002003

18. Fights, S. D. (2015). Workload and Work Environment of Nursing Faculty [Doctoral Dissertation, Capella University]. Capella University.

19. Fu, C. K. \& Shaffer, M. A. (2001). The Tug of Work and Family: Direct and Indirect Domain-Specific Determinants of Work-Family Conflict. Personnel Review, 30(5), 502-522. 
https://doi.org/10.1108/EUM0000000005936

20. Glaser, D. N., Tatum, B. C., Nebeker, D. M., Sorenson, R. C. \& Aiello, J. R. (1999). Workload and Social Support: Effects on Performance and Stress. Human Performance, 12(2), 155-176. https://doi.org/10.1080/08959289909539865

21. Goh, Z., Ilies, R. \& Wilson, K. S. (2015). Supportive Supervisors Improve Employees' Daily Lives: The Role Supervisors Play in The Impact of Daily Workload on Life Satisfaction via Work-Family Conflict. Journal of Vocational Behavior, 89, 65-73. https://doi.org/10.1016/j.jvb.2015.04.009

22. Greenberg, E. S., Sikora, P., Grunberg, L. \& Moore, S. (2005). Work Teams and Organizational Commitment (Workplace Change Project Working Paper No. WP-012). Boulder, CO: Institute of Behavioral Science, University of Colorado at Boulder, University of Puget Sound.

23. Greenhaus, J. H. \& Beutell, N. J. (1985). Sources of Conflict Between Work and Family Roles. Academy of Management Review, 10(1), 76-88. https://doi.org/10.5465/amr.1985.4277352

24. Greenhaus, J. H., Collins, K. M. \& Shaw, J. D. (2003). The Relation Between Work-Family Balance and Quality of Life. Journal of Vocational Behavior, 63(3), 510-531.

https://doi.org/10.1016/S0001-8791(02)00042-8

25. Greenhaus, J. H., Parasuraman S., Granrose C. S., Rabinowitz S. \& Beutell N. J. (1989). Sources of Work- Family Conflict Among Two Career Couples. Journal of Vocational Behavior, 34(2), 133-153. https://doi.org/10.1016/0001-8791(89)90010-9

26. Hooper, D., Coughlan, J. \& Mullen, M. (2008). Structural Equation Modelling: Guidelines For Determining Model Fit. Dublin Institute of Technology Articles, 61(1), 53-60.

27. Ilies, R., Schwind, K. M., Wagner, D. T., Johnson, M. D., Derue, D. S. \& Ilgen, D. R. (2007). When Can Employees Have a Family Life? The Effects of Daily Workload and Affect on Work-Family Conflict and Social Behaviors at Home. Journal of Applied Psychology, 92(5), 1368-1379.

https://doi.org/10.1037/0021-9010.92.5.1368

28. Imoisili, O. A. (1985). Task Complexity, Budget Style of Evaluating Performance and Managerial Stress: an Empirical Investigation [Doctoral dissertation, University of Pittsburgh]. University of Pittsburgh.

29. Joyce, K., Pabayo, R., Critchley, J. A. \& Bambra, C. (2010). Flexible Working Conditions and Their Effects on Employee Health and Wellbeing. Cochrane Database of Systematic Reviews, (2). https://doi.org/10.1002/14651858.CD008009.pub2

30. Kahn, R. L., Wolfe, D. M., Quinn, R. P., Snoek, J. D. \& Rosenthal, R. A. (1964). Organizational Stress: Studies in Role Conflict and Ambiguity. Social Forces, 43(4), 591-592.

31. Katz, D. \& Kahn, R. L. (1978). The Social Psychology of Organizations. Wiley.

32. Keser, A. (2006). Çağrı Merkezi Çalışanlarında İş Yükü Düzeyi ile İş Doyumu İlişkisinin Araştırılması. Kocaeli Üniversitesi Sosyal Bilimler Enstitüsü Dergisi, (11), 100-119.

33. Kirmeyer, S. L. \& Dougherty, T. W. (1988). Work Load, Tension, And Coping: Moderating Effects of Supervisor Support. Personnel Psychology, 41(1), 125-139. https://doi.org/10.1111/j.1744-6570.1988. tb00635.x

34. Kossek, E. E., Pichler, S., Bodner, T. \& Hammer, L. B. (2011). Workplace Social Support and WorkFamily Conflict: A Meta-Analysis Clarifying The Influence of General and Work-Family-Specific Supervisor and Organizational Support. Personnel Psychology, 64(2), 289-313. https://doi.org/10.1111/j.1744-6570.2011.01211.x

35. Lapierre, L. M. \& Allen, T. D. (2006). Work-Supportive Family, Family-Supportive Supervision, Use of Organizational Benefits, and Problem-Focused Coping: Implications for Work-Family Conflict and Employee Well-Being. Journal of Occupational Health Psychology, 11(2), 169-181. https://doi.org/10.1037/1076-8998.11.2.169

36. Lu, L., Kao, S. F., Chang, T. T., Wu, H. P. \& Cooper, C. L. (2008). Work/Family Demands, Work Flexibility, Work/Family Conflict, and Their Consequences at Work: A National Probability Sample in Taiwan. International Journal of Stress Management, 15(1), 1-21. https://doi.org/10.1037/1072-5245.15.1.1 
37. Major, D. A., Fletcher, T. D., Davis, D. D. \& Germano, L. M. (2008). The Influence of Work-Family Culture and Workplace Relationships on Work Interference with Family: A Multilevel Model. Journal of Organizational Behavior, 29(7), 881-897. https://doi.org/10.1002/job.502

38. Mesmer-Magnus, J., Murase, T., Dechurch, L. A. \& Jiménez, M. (2010). Coworker Informal Work Accommodations to Family: Scale Development and Validation. Educational and Psychological Measurement, 70(3), 511-531. https://doi.org/10.1177/0013164409355687

39. Michel, J. S., Mitchelson, J. K., Pichler, S. \& Cullen, K. J. (2010). Clarifying Relationships among Work and Family Social Support, Stressors, and Work-Family Conflict. Journal of Vocational Behavior, 76(1), 91-104. https://doi.org/10.1016/j.jvb.2009.05.007

40. Muse, L. A. \& Pichler, S. (2011). A Comparison of Types of Support for Lower-Skill Workers: Evidence for The Importance of Family Supportive Supervisors. Journal of Vocational Behavior, 79(3), 653-666. https://doi.org/10.1016/j.jvb.2011.04.005

41. Ng, T. W. \& Sorensen, K. L. (2008). Toward a Further Understanding of The Relationships Between Perceptions of Support and Work Attitudes: A Meta-Analysis. Group Organization \& Management, 33(3), 243-268. https://doi.org/10.1177/1059601107313307

42. O’Driscoll, M. P., Poelmans, S., Spector, P. E., Kalliath, T., Allen, T. D., Cooper, C. L. \& Sanchez, J. I. (2003). Family-Responsive Interventions, Perceived Organizational and Supervisor Support, WorkFamily Conflict, and Psychological Strain. International Journal of Stress Management, 10(4), 326-344. https://doi.org/10.1037/1072-5245.10.4.326

43. Ovla, H. D. \& Taşdelen, B. (2012). Aykırı Değer Yönetimi. Mersin Üniversitesi Sağlık Bilimleri Dergisi, 5(3), 1-8.

44. Özmete, E. \& Eker. I, (2012). İş-Aile Yaşamı Çatışması ve Roller: Kamu Sektörü Örneğinde Bir Değerlendirme. Çalışma İlişkileri Dergisi, 3(2), 1-23.

45. Podsakoff, N. P. (2003). Common Method Biases In Behavioral Research: A Critical Review of The Literature and Recommended Remedies. Journal of Applied Psychology, 88(5), 879-903. https://doi.org/10.1037/0021-9010.88.5.879

46. Preacher, K. J. \& Hayes, A. F. (2004). SPSS And SAS Procedures for Estimating Indirect Effects In Simple Mediation Models. Behavior Research Methods, Instruments, \& Computers, 36(4), 717-731. https://doi.org/10.3758/BF03206553

47. Reiche, B. S., Kraimer, M. L. \& Harzing, A. (2011). Why Do International Assignees Stay? An Organizational Embeddedness Perspective. Journal of International Business Studies, 42(4), 521-544. https://doi.org/10.1057/jibs.2011.5

48. Rousseau, V., Aube, C. \& Savoie, A. (2006). Teamwork Behaviors: A Review and an Integration of Frameworks. Small Group Research, 37(5), 540-570. https://doi.org/10.1177/1046496406293125

49. Salvucci, D. D. \& Taatgen, N. A. (2008). Threaded Cognition: An Integrated Theory of Concurrent Multitasking. Psychological Review, 115(1), 101-130. https://doi.org/10.1037/0033-295X.115.1.101

50. Shantz, A., Arevshatian, L., Alfes, K. \& Bailey, C. (2016). The Effect of HRM Attributions on Emotional Exhaustion and The Mediating Roles of Job Involvement and Work Overload. Human Resource Management Journal, 26(2), 172-191. https://doi.org/10.1111/1748-8583.12096

51. Shirom, A., Toker, S., Alkaly, Y., Jacobson, O. \& Balicer, R. (2011). Work-Based Predictors of Mortality: A 20-Year Follow-Up of Healthy Employees. Health Psychology, 30(3), 268-275.

https://doi.org/10.1037/a0023138

52. Staines, G. L. (1980). Spillover Versus Compensation: A Review of The Literature on The Relationship Between Work and Non-Work. Human Relations, 33, 111-129. https://doi.org/10.1177/001872678003300203

53. Thompson, C. A. \& Prottas, D. J. (2006). Relationships Among Organizational Family Support, Job Autonomy, Perceived Control, and Employee Well-Being. Journal of Occupational Health Psychology, 11(1), 100-118. https://doi.org/10.1037/1076-8998.10.4.100 
54. Turgut, T. (2011). Çalışmaya Tutkunluk: İş Yükü, Esnek Çalişma Saatleri, Yönetici Desteği ve İş-Aile Çatışmasi ile İliş̧kileri. Atatürk Üniversitesi İktisadi ve İdari Bilimler Dergisi, 25(3-4).

55. Voydanoff, P. (1988). Work Role Characteristics, Family Structure Demands, and Work/Family Conflict. Journal of Marriage and Family, 50(3), 749-761. https://doi.org/10.2307/352644

56. Wang, M., Liu, S., Zhan, Y. \& Shi, J. (2010). Daily Work-Family Conflict and Alcohol Use: Testing The Cross-Level Moderation Effects of Peer Drinking Norms and Social Support. Journal of Applied Psychology, 95(2), 377-386. https://doi.org/10.1037/a0018138

57. Weigl, M., Stab, N., Herms, I., Angerer, P., Hacker, W. \& Glaser, J. (2016). The Associations of Supervisor Support and Work Overload with Burnout and Depression: A Cross-Sectional Study In Two Nursing Settings. Journal of Advanced Nursing, 72(8), 1774-1788. https://doi.org/10.1111/jan.12948

58. Ylldırım, D. \& Aycan, Z. (2008). Nurses' Work Demands and Work-Family Conflict: A Questionnaire Survey. International Journal of Nursing Studies, 45(9), 1366-1378. https://doi.org/10.1016/j.ijnurstu.2007.10.010

59. Yoon, J. \& Thye, S. (2000). Supervisor Support in The Work Place: Legitimacy and Positive Affectivity. The Journal of Social Psychology, 140(3), 295-316. https://doi.org/10.1080/00224540009600472 